\title{
SIMBOLOGIA Y POLITICA \\ Los juegos del poder detrás del fuego olímpico
}

Por: Edgar Gustavo Angel G.

El primer acercamiento con la majestuosidad de los Juegos Olímpicos, tuvo lugar en el Teatro Mogador, en pleno corazón de Bogotá. El Gobierno japonés, para exaltar la organización de las justas que celebraría en 1964, contrató a uno de sus mejores directores cinematográficos, a él le encargó la misión de capturar las escenas más relevantes de las justas que tendrían como sede Tokio ese verano.

Todavía guardo en mi memoria dos sucesos relacionados con esa proyección. El primero, la risa que generó en nuestra familia y vecinos de espectáculo la pregunta de la menor de mis hermanas, entonces de 6 años, cuando apagaron las luces de la sala: ¿cómo se llama aquí esta oscuridad? El segundo, más vívido por las evocaciones que aún me provoca, la imagen en cámara lenta de un hombre corriendo descalzo por las calles de Tokio, su rostro descompuesto y sudoroso refleja el esfuerzo de un cuerpo que avanza por el pavimento que arde por el sol de mediodía. Ese hombre simbolizó para nuestra generación el heroísmo tercermundista reflejado en tul sargento etíope, Abeve Bikila; doble presea dorada en la maratón.

Cuatro años más tarde, comencé a reflexionar sobre el fino tejido que soporta, el robusto andamiaje olímpico.

Cientos de estudiantes salieron a protestar a la Plaza de Tlatelolco. Se oponían a la opulencia y exuberancia de la olimpíada, que contrastaba con la pobreza de los vecindarios que rodeaban los principales escenarios. Sus voces y las del mundo fueron acalladas. El espectáculo continué, sin embargo la expulsión de Sudáfrica como rechazo a su política de segregación racial y los puños envueltos en medias negras con los brazos erguidos de T. Smith y J. Carlos, que simbolizarían, para unos el poder negro y para otros, el respaldo al clandestino movimiento Panteras Negras, produjeron una cortina de humo sobre la nueva técnica de salto alto que propuso Dick Fosbury y el supersalto de 8,90 metros, en largo, de "Bob" Beamon.

Septiembre Negro. Un comando palestino tiñó de rojo la olimpíada que tuvo como sede a Munich en 1972. Once deportistas murieron, lo mismo que sus captores, la guerra palestino-israelí encontró un nuevo escenario. Los comandos irrumpieron en la villa, secuestro, exigencias, respuesta militar de grupos antiterroristas judíos.

Cuatro años más tarde, en Montreal, el primer Ministro Pierre Trodeau anunció que no permitiría la entrada en Canadá de los atletas de la República de China con capital en Taiwán, se propuso, como fórmula de compromiso, que aquellos chinos desfilaran bajo su bandera y con su himno, pero con el nombre geográfico de Taiwán. Con el apoyo de Estados Unidos pudieron mantener una posición firme y desfilar como China Nacionalista.

No bien concluido ese problema, algunos países africanos solicitaron la exclusión del equipo de Nueva Zelanda, porque un equipo de rugby, deporte no olímpico, de aquel país, había jugado unos partidos con Sudáfrica país excluido del movimiento olímpico.

\footnotetext{
* Profesor Facultad de Educación Física, U.P.N.
} 
Sin embargo, fueron las minorías las primeras víctimas de las incestuosas relaciones política olimpísmo. Un indio norteamericano, Jim Torpe y un negro de esa misma nación, perdieron sus preseas en Estocolmo 1912. Al primero se le acusó de haber jugado béisbol profesional, el segundo jamás salió del camerino, el entrenador lo retuvo; un blanco se colgó la dorada.

Las delegaciones de Alemania, Austria y Hungría no pudieron estar presentes en las Olimpíadas de Amberes (1920) ni en París (1924). Se les excluyó del circuito por haber desencadenado la Primera Guerra Mundial.

Adolfo Hitler ejerció de anfitrión de los Juegos Olímpicos de 1936, que tuvieron como sede a Berlín. Los triunfos de Jesse Owens en los 100, 200 y largo opacaron la fiesta de la supremacía aria y obligaron el retiro del Führer del Estadio. El hombre que sumió a Europa en la Segunda Guerra Mundial se resistió a entregar la tercera presea dorada a un negro americano, a quien consideraba inferior.

En Helsinki, 1952, se libró el primer round de la guerra fría en el deporte, pues por primera vez participé la Unión de Repúblicas Soviéticas Socialistas, con un modesto cuarto lugar en el medallero general.

Durante los juegos de Melbourne, 1956, España, Holanda y Suiza declinaron la invitación en protesta por la invasión soviética a Hungría. Similar actitud adoptaron Líbano, Egipto e Irak que presionaban la salida de tropas de la ONU del Canal de Suez. China Continental presioné la salida de China Nacionalista, la negativa del COI a esa exigencia, determinó la salida de la delegación del país más poblado de la tierra.

La modalidad del boicot regresó al escenario olímpico en 1980. Estados Unidos y algunos de sus aliados, en protesta por la invasión a Afganistán, decidieron no participar en Moscú. Cuatro años más tarde, Rusia y sus aliados no asistieron a los Ángeles. Corea del Norte y otros cuatro países no fueron a Seúl 88.

La Guerra Fría y sus estrechos lazos con el deporte fueron derrotados en 1989, por un político que con los términos glashnot y perestroika derribé tanto el muro de Berlín, como el ideológico que enfrentaba dos modelos económicos cada cuatro años en el gran circo olímpico. Mijail Gorvachov propicié un rayo de esperanza al final de la intromisión política en el deporte, luz que como la del fuego olímpico, trata de ser opacada por los enemigos del espíritu de reconciliación y hermandad, que desde la antigua Grecia se pregona para las justas deportivas.

"En la Grecia clásica, los Juegos Olímpicos, así como los juegos Pitios de Delfos, eran llamados Panhelénicos, porque unían a todos los pueblos griegos e incluso llegaban a interrumpir las guerras, pues eran más importantes que ellas. Convocaban no sólo al deporte sino al Arte, la Religión, la Poesía, la Música, porque para los griegos eran dominios inseparables; a tal punto, que la mítica Olimpia no era un pueblo o ciudad poblada sino una agrupación de templos y Palestras (zonas de entrenamiento), algo así como un lugar virtual donde cada cuatro años se reunían todos para competir por la rama de laurel hecha corona para el ganador".

"Como contrapartida, hoy se realizan en ciudades densamente pobladas, obedeciendo a intereses que hagan rentable tamaño esfuerzo, aunque la economía y la heroicidad se 
den a veces de patadas en otras palestras menos griegas, donde el marketing, si bien no es Júpiter, ocupa el trono de esos altares"1.

Por esa razón se designé a Sydney como sede de la primera olimpíada del nuevo milenio, igual, como un gesto político de reconciliación entre minorías aborígenes y colonizadores que intentaron aniquilarlas, se designé a Katy Freeman como el modelo que las uniría, a través del encuentro del fuego, el aire, el agua y ella en representación de la madre tierra. Todos símbolos, como lo anuncia su etimología (symbolon: lo que une) enemigos de lo que fragmenta, significado en lo diabólico (lo que separa o desune) de los individualismos más sectarios y enfermizos.

Hoy entiendo por qué, el preciado tesoro que Prometeo robara a los dioses me evoca un teatro en el centro de Bogotá y un hombre con rostro de alegría rompiendo la cinta para ganar la maratón en la única película que se ha hecho sobre los Juegos Olímpicos.

\footnotetext{
${ }^{1}$ Espiño, Gabriel. Los límites del fuego griego. Tiempos del Mundo. PG B34 . 21 septiembre 2000.
} 